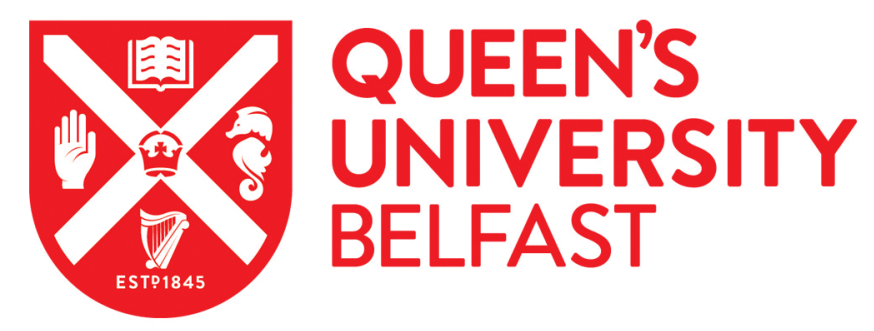

\title{
Multi-walled carbon nanotubes: A cytotoxicity study in relation to functionalization, dose and dispersion
}

Zhou, L., Forman, H. J., Ge, Y., \& Lunec, J. (2017). Multi-walled carbon nanotubes: A cytotoxicity study in relation to functionalization, dose and dispersion. Toxicology in Vitro, 42, 292-298.

https://doi.org/10.1016/j.tiv.2017.04.027

\section{Published in:}

Toxicology in Vitro

\section{Document Version:}

Peer reviewed version

Queen's University Belfast - Research Portal:

Link to publication record in Queen's University Belfast Research Portal

\section{Publisher rights}

Copyright 2017 Elsevier.

This manuscript is distributed under a Creative Commons Attribution-NonCommercial-NoDerivs License

(https://creativecommons.org/licenses/by-nc-nd/4.0/), which permits distribution and reproduction for non-commercial purposes, provided the author and source are cited.

\section{General rights}

Copyright for the publications made accessible via the Queen's University Belfast Research Portal is retained by the author(s) and / or other copyright owners and it is a condition of accessing these publications that users recognise and abide by the legal requirements associated with these rights.

Take down policy

The Research Portal is Queen's institutional repository that provides access to Queen's research output. Every effort has been made to ensure that content in the Research Portal does not infringe any person's rights, or applicable UK laws. If you discover content in the Research Portal that you believe breaches copyright or violates any law, please contact openaccess@qub.ac.uk. 
Multi-walled carbon nanotubes: a cytotoxicity study in relation to functionalization, dose and dispersion

Lulu Zhou ${ }^{1 *}$, Henry Jay Forman ${ }^{1}$, Yi $G^{2}$ and Joseph Lunce ${ }^{3}$

${ }^{1}$ Leonard Davis School of Gerontology, University of Southern California, Los

Angeles, CA, 90089-0091, USA

${ }^{2}$ School of Pharmacy, Queen's University, Belfast BT9 7BL, UK

${ }^{3}$ Centre for Biomedical Engineering, Cranfield University, Cranfield, Bedfordshire,

MK43 0AL, UK

${ }^{*}$ To whom correspondence should be addressed.

E-mail: luluzhou@usc.edu

Tel: 6262334752 


\begin{abstract}
Chemical functionalization broadens carbon nanotube (CNT) applications, conferring new functions, but at the same time potentially altering toxicity. Although considerable experimental data related to CNT toxicity, at the molecular and cellular levels, have been reported, there is very limited information available for the corresponding mechanism involved (e.g. cell apoptosis and genotoxicity). The threshold dose for safe medical application in relation to both pristine and functionalized carbon nanotubes remains ambiguous. In this study, we evaluated the in vitro cytotoxicity of pristine and functionalized $(-\mathrm{OH},-\mathrm{COOH})$ multi-walled carbon nanotubes (MWCNTs) for cell viability, oxidant detection, apoptosis and DNA mutations, to determine the non-toxic dose and influence of functional group in a human lung-cancer cell line exposed to 1-1000 $\mu \mathrm{g} / \mathrm{ml}$ MWCNTs for 24, 48 and 72 h. The findings suggest that pristine MWCNTs induced more cell death than functionalized MWCNTs while functionalized MWCNTs are more genotoxic compared to their pristine form. The level of both dose and dispersion in the matrix used should be taken into consideration before applying further clinical applications of MWCNTs.
\end{abstract}

Keywords: Multi-walled Carbon Nanotubes; Cytotoxicity; Functionalization; Viability; Reactive Oxygen Species; Apoptosis; DNA Damage 


\section{Introduction}

Carbon nanotubes (CNTs) are a family of nanomaterials made up entirely of carbon. In this family, structurally multi-walled carbon nanotubes (MWCNTs) consist of multiple layers of graphite superimposed and rolled in on themselves to form a tubular shape. MWCNTs are of special interest for industry and have been increasingly utilised as advanced nanovectors in drug/gene delivery systems (Vashist et al., 2011). They possess significant advantages including high surface area, well-defined morphologies and unique optical as well as electrical properties, in addition to their super mechanical strength and thermal conductivity.

Apart from their special physico-chemical properties however, MWCNTs present low bio-compatibility in most biological and chemical environments, already generating some health and environmental concerns. Although the toxicological effects of MWCNTs have been investigated, existing data are far from adequate. It has been suggested that the related factors of MWCNTs such as fibre dose (He et al., 2011), length (Johnston et al., 2010), diameter (Nagai et al., 2011), surface area (Kim et al., 2011), tendency to agglomerate (Kim et al., 2011) and dispersibility in media (Kim et al., 2011) could influence toxicity and reactivity of CNTs in vitro and in vivo. For example, a recent study showed that the pathogenicity observed for asbestos-like long pristine MWCNTs could be obviated if their effective length is decreased (Ali-Boucetta et al., 2013). Elgrabli further reported that CNTs dispersed in bovine serum albumin (BSA) exhibited significantly reduced toxic (Elgrabli et al., 2007). Other researchers observed that agglomerates induced more pronounced cytotoxic effects than asbestos fibres at the same mass concentrations (Wick et al., 2007).

It is worth noting that, as previously reported, the functionalization/modification of the structure of MWCNTs can optimise their solubility and dispersion, allowing innovative applications in materials (Martín et al., 2013a), electronics (Castranova et al., 2013), chemical processing (Martín et al., 2013b) and energy management 
(Mauter and Elimelech, 2008). However, the functionalization of MWCNTs produced additional controversy regarding their toxicity. For example, Vashist et al (Vashist et al., 2011) and Mali et al. (Mali et al., 2011) reported that functionalized CNTs were able to exhibit very low toxicity and higher propensity to cross cell membranes, increasing their potential for drug and gene delivery. On the contrary, Magrez et al. showed that the toxicity of MWCNT, in human lung-tumor cell lines, was increased when carboxyl and hydroxyl groups were present on their surface (Magrez et al., 2006). A study conducted by Patlolla et al. performed on bone marrow cells of mice exposed to $-\mathrm{COOH}$ functionalized and pristine MWCNTS, found that functionalized MWCNTs had higher clastogenic and genotoxic potential than non-functionalized CNTs (Patlolla et al., 2010).

Data on genotoxicity induced by pristine and functionalized MWCNTs are still very limited. Until very recently, their effect on DNA damage has been investigated but the accumulation of 8-OHdG in DNA was not found (Ogasawara et al., 2012). Information about apoptosis induced by MWCNT is also incomplete although pristine MWCNTs does not appear to cause apoptosis in lung cells (Ursini et al., 2012).

Hence, in this study, we investigated the effect of dispersion of two most frequently used functionalized multi-walled carbon nanotubes (i.e. OH-MWCNTs and COOH-MWCNTs) on A549 cell line apoptosis and DNA damage, in comparison with pristine MWCNTs. As the primary route of human exposure to MWCNTs is via inhalation, the A549 cell line, a lung cancer cell line, was selected for this study. More importantly and interestingly, cell proliferation and oxidative stress were also investigated in order to provide a more comprehensive understanding of the potential mechanism of toxicity as well as the threshold dose for their safe medical applications. 


\section{Materials and Methods}

\section{Material}

Prisitine multi-walled carbon nanotubes (P-MWNCNTs), carboxylic acid, hydroxy functionalized MWCNTs (COOH-MWCNTs, OH-MWCNTs) were purchased at Cheap Tubes Inc. (United States, Sku-030111, 030112, 030113). External diameter: 13-18nm; functional group content: $7.0 \%+/-1.5 \%$; length: $1-12 \mu \mathrm{m}$; purity: $>99 \mathrm{wt} \%$ (Figure 1).

\section{Preparation of BSA solution}

Five milligram nanotubes were suspended in FBS free medium which contains $0.5 \%$ BSA at $1000 \mu \mathrm{g} / \mathrm{ml}$. Then they were diluted into 316, 200, 100, 50, 36, 20, 103.6 and $1 \mu \mathrm{g} / \mathrm{ml}$.

\section{Cell culture}

Human lung epithelial cell line (A549) was obtained as a gift from Dr Huijun Zhu. Passage number is 76-79 according to ATCC website (http://atcc.custhelp.com/app/answers/detail/a id/3/ /high-passage-number,

27/06/2014). Before using, bacterial, yeast and fungal contamination were checked under a microscope for mycoplasma using Gibco's Mycotect kit (Cat.No. 15672017). A549 cells were cultured in F12/DMEM (Dulbecco's Modified Eagle Medium) (Invitrogen, United Kingdom) supplemented with 10\% fetal calf serum (sigma, United Kingdom) at $37^{\circ} \mathrm{C}$ in $5 \% \mathrm{CO}_{2}$. All the experiments were conducted using the same passage number. Six T-75 flasks of cells were collected and re-suspended in freezing media ( $90 \%$ serum $+10 \%$ dimethylsulfoxide), and then they were aliquoted into $1 \mathrm{ml}$ vials. The cells were frozen and kept at $-20^{\circ} \mathrm{C}$ for $2 \mathrm{~h}$ and then at $-80^{\circ} \mathrm{C}$ overnight. The cells were then moved to a $-150^{\circ} \mathrm{C}$ freezer the next day. This protocol was repeated in each passage. 


\section{Cell viability}

Two hundred microliter of cells were seeded in 96-well plates at $2 \times 10^{4}$ cells $/ \mathrm{ml}$ per well and treated with carbon nanotubes the following day for $24 \mathrm{~h}$. Before measurement, cells were washed with PBS one time and $100 \mu$ new medium was added per well. The tetrazolium salt WST-1 cell proliferation reagent was added to cells at the recommended concentration $\left(5 \mu \mathrm{l} /\right.$ well) and incubated at $37^{\circ} \mathrm{C}$ in a humidified atmosphere of $5 \% \mathrm{CO}_{2}$ for $3 \mathrm{~h}$. Plates were shaken for $1 \mathrm{~min}$ and absorbance was measured at $405 \mathrm{nM}$ with a Varioskan Flash Multimode plate reader (Thermo Scientific). Unexposed cells were used as negative control.

\section{Cell membrane integrity}

Lactate dehydrogenase release was measured as an indicator of cell membrane damage using an LDH assay kit (Cytotoxicity Detection Kit, sigma, United Kingdom) of the culture medium of cells exposed to MWCNTs for 24 h. $200 \mu$ l cells were seeded in 96-well plates at $2 \times 10^{4}$ cells $/ \mathrm{ml}$ per well and treated with carbon nanotubes the following day for $24 \mathrm{~h}$. Aliquots $(50 \mu \mathrm{l})$ of supernatant and reaction mixture were transferred into corresponding wells of an optically clear 96-well plate and incubated for $30 \mathrm{~min}$ at $25^{\circ} \mathrm{C}$, protecting the plate from the light. The increase in enzyme activity directly correlates to the amount of formazan produced by reduction of the tetrazolium salt. The absorbance was measured at $490 \mathrm{~nm}$ using a Varioskan Flash Multimode plate reader. A background and negative controls were obtained by LDH activity measurement of assay medium and unexposed cell medium, respectively.

\section{Oxidant detection}

The production of oxidants was assessed on intact cells in 96 wells microplates using the dichlorofluorescein (DCF) assay. Oxidation of the hydrolysed product of DCF-DA to DCF is not specific for a particular reactive species, but its oxidation generally correlates with oxidative stress. Cells at $2 \times 10^{4} / \mathrm{ml}$ were incubated with MWCNTs at concentrations 2,20 and $50 \mu \mathrm{g} / \mathrm{ml}$ for $6 \mathrm{~h}$ firstly. $2^{\prime}, 7^{\prime}$-dichlorofluorescein Page 6 of 30 
diacetate (DCFH-DA) (Sigma, United Kingdom) was dissolved in culture medium to give a final concentration of $20 \mu \mathrm{M}$. Total DCF fluorescence was detected by incubation with DCFH-DA solution $(200 \mu \mathrm{l})$ at $37{ }^{\circ} \mathrm{C}$ for $30 \mathrm{~min}$, and then washed with PBS (phosphate buffered saline) and resuspended in $100 \mu 1$ of PBS. The formation of the fluorescence-oxidized derivative of DCF was monitored at an emission wavelength of $520 \mathrm{~nm}$ and excitation wavelength of $485 \mathrm{~nm}$ with Varioskan Flash Multimode plate reader. DCF fluorescence was expressed as percentage of control.

\section{Apoptosis detection}

A549 cell apoptosis was evaluated by Annexin V-FITC, PI apoptosis detection kit (Ebioscience, United Kingdom). Annexin V binds to phosphatidylserine that moves to the outer leaflet of cells at the beginning of apoptosis. Necrotic cells were stained with both Annexin V and PI.

Cells were cultured in 6 well plate at $1 \times 10^{5} / \mathrm{ml}$ per well and then exposed for $48 \mathrm{~h}$ to MWCNTs culture medium the following day; control cells were incubated without MWCNTs. Before detection, the cell culture medium were removed and washed by cold PBS. Then the detached cells were centrifuged at $1200 \mathrm{rpm}$ and placed on ice. After a 10 min incubation period with $2 \mu \mathrm{l}$ Annexin-V and $4 \mu \mathrm{l}$ P, cells were analysed by flow cytometer (Accuri C6).

\section{DNA damage}

A549 cells were seeded in 6-well plates at $1 \times 10^{5} / \mathrm{ml}$ exposed to pristine and functionalized MWCNTs at $50 \mu \mathrm{g} / \mathrm{ml}$ for $72 \mathrm{~h}$. Negative control cells were incubated without MWCNTs. The concentration of 8-oxodeoxyguanosine (8-OHdG) in DNA, indicating oxidative DNA damage, was quantified by colorimetric antibody ELISA assay that has been widely used for the $8-\mathrm{OHdG}$ detection.

1. DNA extraction 
DNA isolation from cells treated with MWCNTs was carried out with a DNA extraction kit from QIAGEN (United Kingdom). The assay was performed according to manufacturer's instruction. After exposure to MWCNTs, cells were treated with cell lysis buffer and then centrifuged at $300 \times \mathrm{g}$ for $3 \mathrm{~min}$, the supernatant discarded, and the tube inverted on a clean piece of absorbent paper. The DNA pellets were cleaned using $600 \mu \mathrm{g} \mathrm{70 \%} \mathrm{ethanol} \mathrm{and} \mathrm{then} \mathrm{centrifuged} \mathrm{at} 10000 \times \mathrm{g}$ for $3 \mathrm{~min}$. The supernatant was discarded and the DNA pellets air-dried until dry. The DNA was then dissolved in Tris-EDTA buffer for $30 \mathrm{~min}$ at $65^{\circ} \mathrm{C}$. All the DNA samples were stored at $-20^{\circ} \mathrm{C}$ for later use.

\section{ELISA}

The concentration of 8-OHdG was measured by HT 8-oxo-dG kit (TREVIGEN, United Kingdom) based on ELISA. The assay was performed according to manufacturer's instruction. Briefly, the DNA samples were diluted to $50 \mu \mathrm{g} / \mathrm{ml}$ (Picodrop) and then further diluted 2:3 in Assay Diluent. $25 \mu \mathrm{g}$ 8-OHdG standards and DNA samples were added to each well, followed by adding $25 \mu \mathrm{g}$ monoclonal antibody. Then the plate was covered with film sealer and incubated at $25^{\circ} \mathrm{C}$ for $1 \mathrm{~h}$. After washing the plate 4 times with PBST, add $50 \mu 1$ HRP conjugate to each well, followed by $1 \mathrm{~h}$ incubation. After aspirating and washing with washing solution, the plate was inverted and blotted against clear paper towels and this process was repeated four times. Each well was added $50 \mu 1$ of TACS-Sapphire ${ }^{\mathrm{TM}}$ gently mixed and incubated at $37{ }^{\circ} \mathrm{C}$ for $15 \mathrm{~min}$, then stopped with $50 \mu \mathrm{l}$ of $1 \mathrm{M}$ hydrochloric acid. Assay plates were read at $450 \mathrm{~nm}$ with a plate reader.

\section{Statistical methods}

Three independent experiments were performed. Each concentration was assayed in triplicate, in each independent experiment. The measurements were corrected using absorbance/fluorescence readings from MWCNT addition within a cell-free system. Results were expressed as mean \pm standard deviation (SD). Statistical analysis was 
carried out using analysis of variance (ANOVA), followed by Tukey's multiple comparison tests. Differences were considered significant from $\mathrm{P}<0.05$.

\section{Results}

\section{Cell viability}

In our cell viability study, the cell proliferation reagent WST-1 was used to evaluate cell viability in response to pristine and functionalized MWCNTs. Figure 2 describes the comparison of the concentration-response curves obtained for each MWCNT [Bottom (minimum effect), IC50 (concentration required for $50 \%$ of cell viability inhibition), Top (maximum effect)]. IC 50 of pristine MWCNTs $(255.2 \mu \mathrm{g} / \mathrm{ml})$ were significant different from $\mathrm{IC}_{50}$ of $-\mathrm{OH}$ and $-\mathrm{COOH}$ functionalized MWCNTs (2198, $2456 \mu \mathrm{g} / \mathrm{ml}) . \mathrm{P}<0.0001$.

\section{LDH}

LDH release from cells treated with MWCNTs was also assessed. The increase of LDH activity in cell culture medium, indicative of cell membrane damage was detectable as early as $6 \mathrm{~h}$ after treatment (data are not shown). Figure 3 shows the results obtained at $24 \mathrm{~h}$. The effect on LDH leakage was not significant at 20 and 50 $\mu \mathrm{g} / \mathrm{ml}$ with all three MWCNTs. However, at $200 \mu \mathrm{g} / \mathrm{ml}$, functionalized carbon nanotubes exhibited significant membrane damage while the pristine form showed no significant membrane damage compared with untreated cells (Figure 3).

\section{Aggregation}

It has been reported that MWCNTs showed a very good dispersion in $0.5 \%$ bovine serum albumin (BSA solution) (Elgrabli et al., 2007). A comparison experiment of cell viability test of cells treated with MWCNT and BSA-contained MWCNT 
suspension, from 0 to $200 \mu \mathrm{g} / \mathrm{ml}$, has been conducted in order to evaluate toxicity of more thoroughly dispersed CNTs. Figure 4 shows the pictures of pristine MWCNTs, OH-MWCNTs and COOH-MWCNTs dispersed in cell culture medium without and with BSA, suggesting different extent of aggregation. The samples were suspended at $200 \mu \mathrm{g} / \mathrm{ml}$ and left still for $1 \mathrm{~min}$ in order to allow them to settle and form aggregates. From visual observation, pristine carbon nanotubes had smaller aggregates compared to functionalized carbon nanotubes and the suspension with BSA showed better dispersibilty than those without BSA.

The results of comparison of cell viability with and without $0.5 \%$ BSA (Figure 5) showed that the dispersion of carbon nanotubes was of great importance and significantly increased cell viability. At $50 \mu \mathrm{g} / \mathrm{ml}$, none of the three types of MWCNTs showed significant alterations to cell viability with or without BSA. However, at $200 \mu \mathrm{g} / \mathrm{ml}$, viability of functionalized carbon nanotubes (OH-MWCNTs \& $\mathrm{COOH}-\mathrm{MWCNTs}$ ) treated cells was significantly decreased by adding BSA (the P values of slope difference are 0.01745 and 0.007834 respectively). But with respect to pristine MWCNTs, BSA did not increase cell viability at the same concentration. this indicated that the toxicity of pristine MWCNTs was not changed by adding BSA. These results could be explained by the fact that pristine MWCNTs were well dispersed, so additional BSA did not change the dispersion significantly. Although at $200 \mu \mathrm{g} / \mathrm{ml}$ the absorbance value did not show a significant difference with and without BSA, the $\mathrm{p}$ value of slope difference indicates that the adding BSA made functionalised MWCNTs more toxic (Figure $5 \mathbf{b}$ and c). However, the absorbance values corresponding to pristine MWCNTs at both 50 and $200 \mu \mathrm{g} / \mathrm{ml}$ were significantly higher in the presence than in the absence of BSA. In addition, the slopes of the two curves were not significantly different.

\section{DCF fluorescence}


Oxidative stress plays a role in toxicity induced by carbon nanotubes (Pichardo et al., 2012). In this report, DCF-DA was used to measures oxidizing potential within cells. The results of MWCNTs-induced DCF fluorescence are summarized in Figure 6. A549 cells showed responsiveness following $6 \mathrm{~h}$ exposure of MWCNTs at each concentration. At $2 \mu \mathrm{g} / \mathrm{ml}$ concentration, all three carbon nanotubes did not induce significant DCF fluorescence while cells treated with $20 \mu \mathrm{g} / \mathrm{ml}$ MWCNTs (pristine, $-\mathrm{OH},-\mathrm{COOH})$ induced 5.35, 4.84 and 5.36 fold greater DCF fluorescence than untreated cells respectively. However, a reduction in DCF fluorescence was observed following exposure to MWCNTs at $50 \mu \mathrm{g} / \mathrm{ml}$, which may have been caused by either interference of carbon nanotubes with DCF fluorescence or the loss of cell viability (Figure 2).

\section{Apoptosis}

Flow cytometer analysis of A549 cells treated for $48 \mathrm{~h}$ with three types of MWCNTs revealed apoptosis in response to a dose from $20 \mu \mathrm{g} / \mathrm{ml}$ to $200 \mu \mathrm{g} / \mathrm{ml}$. Functionalized carbon nanotubes elicited a greater dose response and larger apoptotic cell percentage compared with unexposed cells and pristine MWCNTs that was statistically significant starting from $20 \mu \mathrm{g} / \mathrm{ml}$. At $20 \mu \mathrm{g} / \mathrm{ml}$, pristine MWCNT induced 8.5 percent of apoptosis while $-\mathrm{OH}$ and $-\mathrm{COOH}$ functionalized MWCNT caused 2.58 and 1.59 times that of the pristine MWCNTs, respectively. At $50 \mu \mathrm{g} / \mathrm{ml}$, the percentage of apoptosis was increased in response to all three different MWCNTs. Similarly, induction of apoptosis by functionalised MWCNTs was more pronounced with $-\mathrm{OH}$ and $-\mathrm{COOH}$ MWCNTs causing 2.28 and 1.95 times the apoptosis induced by pristine MWCNTs. However, at $200 \mu \mathrm{g} / \mathrm{ml}$, apoptosis induced by both functionalized MWCNTs decreased whilst the percentage of apoptosis induced by pristine MWCNTs continued to increase (Table 1). The percentage of necrosis has not been shown here as they were around $1 \%$, which is much lower than the percentage of apoptosis. In addition, they are not significant different among different groups. 


\section{DNA Damage}

In order to measure oxidative DNA damage after exposure to MWCNTs, 8-oxo-2'-deoxyguanosine (8-oxo-dG), a frequently used biomarker of oxidative DNA damage, was measured. No significant oxidative of DNA damage was observed following the exposure of all the concentrations of MWCNTs. By $72 \mathrm{~h}$ of exposure, all three MWCNTS induced $8-\mathrm{OHdG}$ at $50 \mu \mathrm{g} / \mathrm{ml}$, which become statistically significant for pristine MWCNTs $(0.745 \pm 0.017 \mathrm{ng} / \mathrm{ml})$ compared to negative control $(0.651 \pm 0.014 \mathrm{ng} / \mathrm{ml})$. OH-MWCNTs $(0.998 \pm 0.008 \mathrm{ng} / \mathrm{ml})$ and COOH-MWCNTs $(0.975 \pm 0.034 \mathrm{ng} / \mathrm{ml})$ were 1.40 and 1.31 fold more genotoxic than pristine MWCNTs, respectively (Figure 7). 


\section{Discussion}

MWCNTs are widely used for a variety of commercial products; however, the biological consequences of MWCNT exposure in the environment is still poorly understood. In this study, the cytotoxic effects of functionalized and pristine MWCNTs (Figure 1) were investigated using an experimental in vitro model consisting of the human lung A549 epithelial cell line. Several measurements were applied in order to estimate the effects of potential human exposure. Early and late cellular response to MWCNT were evaluated by measurements of cell cytotoxicity, apoptosis and oxidative stress induced genotoxicity. In addition, non-toxic dose was also investigated in order to evaluate the safety of using such materials therapeutically.

In a study conducted by Srivastava, MWCNTs were found to be non-toxic at concentrations from 0.8 to $10 \mu \mathrm{g} / \mathrm{ml}$ following 24 and $48 \mathrm{~h}$ exposure using the less sensitive MTT assay (Srivastava et al., 2011). This finding is consistent with our cell viability results (Figure 2), suggesting that these concentrations could be applied for biosensor, drug vector or cancer imaging with limited toxicity. Within the concentration range of $50-1000 \mu \mathrm{g} / \mathrm{ml}$, we found that cell viability was altered by MWCNTs in a dose dependent manner. In addition, the result of $\mathrm{IC}_{50}$ detection showed that pristine MWCNTs were relatively more cytotoxic than functionalized MWCNTs (Figure 3). This result could be attributed to functionalized MWCNTs exhibiting higher degree of aggregation than pristine MWCNTs in the medium at high concentration $(200 \mu \mathrm{g} / \mathrm{ml})$. At the same concentration, $-\mathrm{COOH}$ and $-\mathrm{OH}$ functionalized MWCNTs showed a higher level of aggregation than pristine MWCNTs in the medium (F12/DMEM) (Figure 4), possibly due to the stronger bonding between functional groups (e.g. hydrogen bonding and van der Waals interactions) on MWCNTs.

Agglomeration of CNT (Tagmatarchis and Prato, 2004) could cause problems in the investigation of CNT toxicity. Methods to disperse CNT have been reviewed by 
Smart et al. (Smart et al., 2006). The most commonly used method needs utilization of organic solvents. However organic solvents are not suitable for biological studies as they are toxic. Another method commonly employed is utilization of surfactant such as BSA which is biomolecule present in body fluids. A possible explanation of these results was provided by Casey et al. (Casey et al., 2007), in which, a better dispersion was shown to occur in the presence of fetal calf serum and medium. This improved dispersion could be explained by physical absorption of CNT by fetal calf serum-medium proteins including albumin. In order to investigate the link between dispersibility and cytotoxicity, we compared the cell viability of cell exposed to MWCNTs with and without BSA. A study conducted by Li et al. suggested that lower dispersion was more likely to result in settling of the MWCNT at the bottom of the wells (Li et al., 2013), where they make more cellular contact. However, in our experiments, results of functionalized MWCNTs showed that the differences between slopes were significant, demonstrating that carbon nanotubes with better dispersibility actually had increased interactions with cells and thereby decreased cell viability (Figure 5). These results were also supported by Johnston who suggested that only those carbon nanotubes which are not aggregated and free in the medium are able to reach the cytoplasm and subsequently the nucleus (Johnston et al., 2010).

Apoptosis is one of the major factors, which determine the medical application of nanomaterials. Therefore, it is important to learn which modification of CNTs with functional group would activate apoptosis. The data presented in this study revealed that MWCNTs induced less apoptosis compared with functionalized MWCNTs (Table 1), indicating that the presence of $-\mathrm{OH}$ and $-\mathrm{COOH}$ on MWCNTs promotes cell apoptosis. However, the extent of apoptosis was reduced when the functionalized MWCNTs' concentration increased to $200 \mu \mathrm{g} / \mathrm{ml}$. This reduction may be explained by the aggregation at $200 \mu \mathrm{g} / \mathrm{ml}$, which altered the mechanism of cell death from apoptosis to membrane disruption (Figure 3). At lower concentrations, where carbon nanotubes were better dispersed, cell death was mainly due to apoptosis. When 
concentrations were increased to $200 \mu \mathrm{g} / \mathrm{mL}$ cells underwent necrotic cell death due to aggregates in the medium.

Oxidative stress plays an essential role in toxicity induced by carbon nanotubes (Pichardo et al., 2012). During times of environmental stress, the highly increased production of oxidants can result in significant damage to cells by activating cell death. DNA damage was found in Met-5A and A549 cell lines using the comet assay (Cavallo et al., 2012), (Lindberg et al., 2013) when exposed to MWCNTs. Our study showed that functionalized MWCNTs induced significantly higher amount of 8-oxo-dG indicating that functionalized forms of MWCNTs could lead to genotoxicity by damaging DNA (Figure 7). However, understanding of the mechanisms underlying this toxicity still remains incomplete. One view is that CNTs were taken up as nanoneedles which could puncture cell membrane directly and then move to the nucleus ( $\mathrm{Mu}$ et al., 2009). A study carried out by Palomaki further showed that only long, needle-like CNT induced inflammatory activation (Palomäki et al., 2011). Another view is that the induction of oxidative stress is a principle mechanism underlying particle exposure-associated genotoxicity (Van Berlo et al., 2012). DNA damage can occur due to the direct action of hydroxyl radicals (Eastman and Barry, 1992). For MWCNT to produce hydroxyl radicals that could oxidize DNA, they would need to enter the nucleus as hydroxyl radical reacts with targets immediately in the vicitnity where it is produced. While in our study, DCF fluorescence was not significantly different among pristine and functionalised MWCNTs (Figure 6), it must be noted that $8-\mathrm{OHdG}$ is actually a far better indicator of oxidant damage to DNA than the measurement of a dye that has little specificity. In our experiment, functionalized MWNCTs induced more cell damage while DCF fluorescence caused by them was not significantly higher than that caused by the pristine form. It is possible that functionalized MWCNTs have higher propensity to cross cell membranes into the nucleus (Mali et al., 2011), and thereby they increase more genotoxicity as we observed. 


\section{Conclusions}

In conclusion, in this study of pristine and functionalized $(-\mathrm{OH},-\mathrm{COOH})$ multi-walled carbon nanotubes (MWCNTs) caused cell death with a concentration at or above 50 $\mu \mathrm{g} / \mathrm{ml}$ with the mechanism of cell death altered from apoptosis to necrosis as concentration increased. After $48 \mathrm{~h}$ exposure, both apoptosis and DNA damage could be further observed. Pristine MWCNTs are more cytotoxic while functionalized MWCNTs exerted more genotoxicity compared with the pristine form. Toxic effects of MWCNTs were also dependent on the dispersing agents. Cytotoxicity was increased by the presence of BSA which changed dispersibility of MWCNTs in cell culture medium.

Further work is needed to investigate cellular internalization of carbon nanotubes in order to gain better insight into the mechanism of toxicity. In addition, a normal lung fibroblast cell line as well as other cell lines (e.g. skin cell lines) may be employed for further study since different cell lines may show various sensitivities to nanoparticles (Hasan et al., 2012) and cancer cells might be more resistant. Progress has been made, but it clinical applications of MWCNTs will still be limited until a better understanding their health impact on humans is achieved. 


\section{Figure Legends}

Figure 1 Multi-walled carbon nanotubes (MWCNTs). a, pristine MWCNTs; b, OH-MWCNTs; c, COOH-MWCNTs

Figure 2 Cell viability curves of A549 cells were evaluated after $24 \mathrm{~h}$ exposure to pristine MWCNTs, OH-MWCNTs and COOH-MWCNTs with concentrations from 1 to $1000 \mu \mathrm{g} / \mathrm{ml}$. Viability was detected by using the WST-1 assay. Data are represented as mean $\pm \mathrm{SD}$ of triplicate.

Figure 3 LDH release assay. Cytotoxicity of all the cell lines was evaluated after $24 \mathrm{~h}$ exposure to pristine MWCNTs, OH-MWCNTs and COOH-MWCNTs with concentrations from 20 to $200 \mu \mathrm{g} / \mathrm{ml}$. Among these groups, cells treated with 200 $\mu \mathrm{g} / \mathrm{ml} \mathrm{COOH}-\mathrm{MWCNTs}$ was significant different. Data are represented as mean $\pm \mathrm{SD}$ of triplicate. ${ }^{*} \mathrm{p}<0.05, * * \mathrm{p}<0.01$

Figure 4 Photo of MWCNTs in the medium. A-C: pristine MWNCT, OH-MWCNT, COOH-MWCNT in the $\mathrm{BSA}^{-}$medium at $200 \mu \mathrm{g} / \mathrm{ml}$; D-F: MWNCT, OH-MWCNT, COOH-MWCNT in the $\mathrm{BSA}^{+}$medium at $200 \mu \mathrm{g} / \mathrm{ml}$.

Figure 5 Comparison of cell viability with and without $0.5 \%$ BSA in FBS-free medium. The viability of A549 cell was detected by using WST-1 assay following 24 $\mathrm{h}$ incubation with all three types of MWCNTs at concentrations of 0,50 and 200 $\mu \mathrm{g} / \mathrm{ml}$. a, pristine MWCNTs; b, OH-MWCNTs; c, COOH-MWCNTs. Data are represented as mean $\pm \mathrm{SD}$ of triplicate.

Figure 6 DCFH oxidation following $6 \mathrm{~h}$ exposure to various concentrations of MWCNTs in A549 cells. Positive control: $200 \mu \mathrm{M} \mathrm{H}_{2} \mathrm{O}_{2}$. Data are represented as mean \pm SD of triplicate analysis. 
Figure 7 DNA damage induced by MWCNTs following $72 \mathrm{~h}$ exposure at a concentration of $50 \mu \mathrm{g} / \mathrm{ml}$. DNA damage was studied using DNA samples of untreated and MWCNTs treated A549 cells. 8-OHdG was quantified by colorimetric antibody ELISA assay. Data are represented as mean \pm SD of triplicate. ${ }^{* *} \mathrm{p}<0.01$, $* * * \mathrm{p}<0.001$ 


\section{Conflict of interest}

The authors declare that there are no conflicts of interest.

\section{Acknowledgement}

We thank Dr. Huijun Zhu for providing the A549 cell line as a gift, and Adeel Irfan and Dr Natalie Kenny and Dr Alex Charlton for their great help and advice in practice. We also thank Jake Chandler for his technical advice. This work was performed at Cranfield University. Partial support came from ES023864 from the National Institutes of Health. 


\section{References}

ALI-BOUCETTA, H., NUNES, A., SAINZ, R., HERRERO, M. A., TIAN, B., PRATO, M., BIANCO, A. \& KOSTARELOS, K. 2013. Asbestos-like Pathogenicity of Long Carbon Nanotubes Alleviated by Chemical Functionalization. Angewandte Chemie International Edition, n/a-n/a.

CASEY, A., DAVOREN, M., HERZOG, E., LYNG, F. M., BYRNE, H. J. \& CHAMBERS, G. 2007. Probing the interaction of single walled carbon nanotubes within cell culture medium as a precursor to toxicity testing. Carbon, 45, 34-40.

CASTRANOVA, V., SChUlTE, P. A. \& ZUMWALDE, R. D. 2013. Occupational nanosafety considerations for carbon nanotubes and carbon nanofibers. Accounts of Chemical Research, 46, 642-649.

CAVALLO, D., FANIZZA, C., URSINI, C. L., CASCIARDI, S., PABA, E., CIERVO, A., FRESEGNA, A. M., MAIELLO, R., MARCELLONI, A. M., BURESTI, G., TOMBOLINI, F., BELLUCCI, S. \& IAVICOLI, S. 2012. Multi-walled carbon nanotubes induce cytotoxicity and genotoxicity in human lung epithelial cells. Journal Of Applied Toxicology, 32, 454-464.

EASTMAN, A. \& BARRY, M. A. 1992. The origins of DNA breaks: A consequence of DNA damage, DNA repair, or apoptosis? Cancer Investigation, 10, 229-240.

ELGRABLI, D., ABELLA-GALLART, S., AGUERRE-CHARIOL, O., ROBIDEL, F., ROGERIEUX, F., BOCZKOWSKI, J. \& LACROIX, G. 2007. Effect of BSA on carbon nanotube dispersion for in vivo and in vitro studies. Nanotoxicology, 1, 266-278.

HASAN, W., CHU, K., GULLAPALLI, A., DUNN, S. S., ENLOW, E. M., LUFT, J. C., TIAN, S., NAPIER, M. E., POHLHAUS, P. D., ROLLAND, J. P. \& DESIMONE, J. M. 2012. Delivery of multiple siRNAs using lipid-coated PLGA nanoparticles for treatment of prostate cancer. Nano Letters, 12, 287-292.

HE, X., YOUNG, S. H., SCHWEGLER-BERRY, D., CHISHOLM, W. P., FERNBACK, J. E. \& MA, Q. 2011. Multiwalled carbon nanotubes induce a fibrogenic response by stimulating reactive oxygen species production, activating NF- $\mathrm{BB}$ signaling, and promoting fibroblast-to-myofibroblast transformation. Chemical Research in Toxicology, 24, 2237-2248.

JOHNSTON, H. J., HUTCHISON, G. R., CHRISTENSEN, F. M., PETERS, S., HANKIN, S., ASCHBERGER, K. \& STONE, V. 2010. A critical review of the biological mechanisms underlying the in vivo and in vitro toxicity of carbon nanotubes: The contribution of physico-chemical characteristics. Nanotoxicology, 4, 207-246.

KIM, J. S., SONG, K. S., LEE, J. H. \& YU, I. J. 2011. Evaluation of biocompatible dispersants for carbon nanotube toxicity tests. Archives of Toxicology, 85, 1499-1508.

LI, R., WANG, X., JI, Z., SUN, B., ZHANG, H., CHANG, C. H., LIN, S., MENG, H., LIAO, Y.-P., WANG, M., LI, Z., HWANG, A. A., SONG, T.-B., XU, R., YANG, Y., ZINK, J. I., NEL, A. E. \& XIA, T. 2013. Surface Charge and Cellular Processing of Covalently Functionalized Multiwall Carbon Nanotubes Determine Pulmonary Toxicity. ACS Nano, 7, 2352-2368.

LINDBERG, H. K., FALCK, G. C. M., SINGH, R., SUHONEN, S., JÄRVENTAUS, H., VANHALA, E., CATAlÁN, J., FARMER, P. B., SAVOLAINEN, K. M. \& NORPPA, H. 2013. Genotoxicity of short single-wall and multi-wall carbon nanotubes in human bronchial epithelial and mesothelial cells in vitro. Toxicology.

MAGREZ, A., KASAS, S., SALICIO, V., PASQUIER, N., SEO, J. W., CELIO, M., CATSICAS, S., SCHWALLER, B. \& FORRÓ, L. 2006. Cellular toxicity of carbon-based nanomaterials. Nano 
Letters, 6, 1121-1125.

MALI, N., JADHAV, S., KARPE, M. \& KADAM, V. 2011. Carbon nanotubes as carriers for delivery of bioactive and therapeutic agents: An overview. International Journal of Pharmacy and Pharmaceutical Sciences, 3, 45-52.

MARTÍN, O., GUTIERREZ, H. R., MAROTO-VAliENTE, A., TERRONES, M., BLANCO, T. \& BASELGA, J. 2013a. An efficient method for the carboxylation of few-wall carbon nanotubes with little damage to their sidewalls. Materials Chemistry and Physics.

MARTÍN, O., GUTIERREZ, H. R., MAROTO-VAliENTE, A., TERRONES, M., BLANCO, T. \& BASELGA, J. 2013b. An efficient method for the carboxylation of few-wall carbon nanotubes with little damage to their sidewalls. Materials Chemistry and Physics, 140, 499-507.

MAUTER, M. S. \& ELIMELECH, M. 2008. Environmental applications of carbon-based nanomaterials. Environmental Science and Technology, 42, 5843-5859.

MU, Q., BROUGHTON, D. L. \& YAN, B. 2009. Endosomal leakage and nuclear translocation of multiwalled carbon nanotubes: Developing a model for cell uptake. Nano Letters, 9, 4370-4375.

NAGAI, H., OKAZAKI, Y., CHEW, S. H., MISAWA, N., YAMASHITA, Y., AKATSUKA, S., ISHIHARA, T., YAMASHITA, K., YOSHIKAWA, Y., YASUI, H., JIANG, L., OHARA, H., TAKAHASHI, T., ICHIHARA, G., KOSTARELOS, K., MIYATA, Y., SHINOHARA, H. \& TOYOKUNI, S. 2011. Diameter and rigidity of multiwalled carbon nanotubes are critical factors in mesothelial injury and carcinogenesis. Proceedings of the National Academy of Sciences, 108, E1330-E1338.

OGASAWARA, Y., UMEZU, N. \& ISHII, K. 2012. [DNA damage in human pleural mesothelial cells induced by exposure to carbon nanotubes]. Nihon eiseigaku zasshi. Japanese journal of hygiene, 67, 76-83.

PALOMÄKI, J., VÄLIMÄKI, E., SUND, J., VIPPOLA, M., CLAUSEN, P. A., JENSEN, K. A., SAVOLAINEN, K., MATIKAINEN, S. \& ALENIUS, H. 2011. Long, needle-like carbon nanotubes and asbestos activate the NLRP3 inflammasome through a similar mechanism. ACS Nano, 5, 6861-6870.

PATlOlla, A. K., HUSSAIN, S. M., SCHLAGER, J. J., PATlOLlA, S. \& TCHOUNWOU, P. B. 2010. Comparative study of the clastogenicity of functionalized and nonfunctionalized multiwalled carbon nanotubes in bone marrow cells of Swiss-Webster mice. Environmental Toxicology, 25, 608-621.

PICHARDO, S., GUTIÉRREZ-PRAENA, D., PUERTO, M., SÁNCHEZ, E., GRILO, A., CAMEÁN, A. M. \& JOS, Á. 2012. Oxidative stress responses to carboxylic acid functionalized single wall carbon nanotubes on the human intestinal cell line Caco-2. Toxicology In Vitro, 26, 672-677.

SMART, S. K., CASSADY, A. I., LU, G. Q. \& MARTIN, D. J. 2006. The biocompatibility of carbon nanotubes. Carbon, 44, 1034-1047.

SRIVASTAVA, R. K., PANT, A. B., KASHYAP, M. P., KUMAR, V., LOHANI, M., JONAS, L. \& RAHMAN, Q. 2011. Multi-walled carbon nanotubes induce oxidative stress and apoptosis in human lung cancer cell line-A549. Nanotoxicology, 5, 195-207.

TAGMATARCHIS, N. \& PRATO, M. 2004. Functionalization of carbon nanotubes via 1,3-dipolar cycloadditions. Journal of Materials Chemistry, 14, 437-439.

URSini, C. L., CAVAllo, D., FreSEGNA, A. M., CiERVO, A., MAIEllo, R., BURESTI, G., 
CASCIARDI, S., TOMBOLINI, F., BELLUCCI, S. \& IAVICOLI, S. 2012. Comparative cyto-genotoxicity assessment of functionalized and pristine multiwalled carbon nanotubes on human lung epithelial cells. Toxicology in Vitro, 26, 831-840.

VAN BERLO, D., CLIFT, M., ALBRECHT, C. \& SCHINS, R. 2012. Carbon nanotubes: An insight into the mechanisms of their potential genotoxicity. Swiss Medical Weekly, 142.

VASHIST, S. K., ZHENG, D., PASTORIN, G., AL-RUBEAAN, K., LUONG, J. H. T. \& SHEU, F. S. 2011. Delivery of drugs and biomolecules using carbon nanotubes. Carbon, 49, 4077-4097.

WICK, P., MANSER, P., LIMBACH, L. K., DETTLAFF-WEGLIKOWSKA, U., KRUMEICH, F., ROTH, S., STARK, W. J. \& BRUININK, A. 2007. The degree and kind of agglomeration affect carbon nanotube cytotoxicity. Toxicology Letters, 168, 121-131. 
Figure 1

a

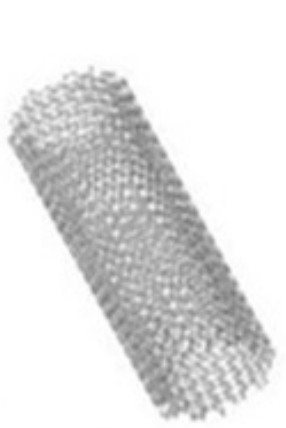

b

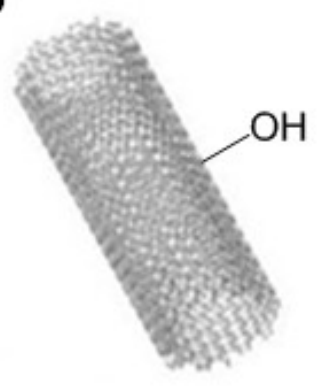

C

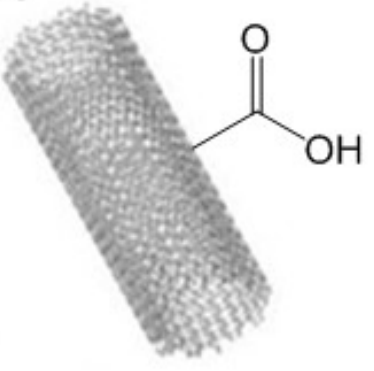


Figure 2

concentration response curve

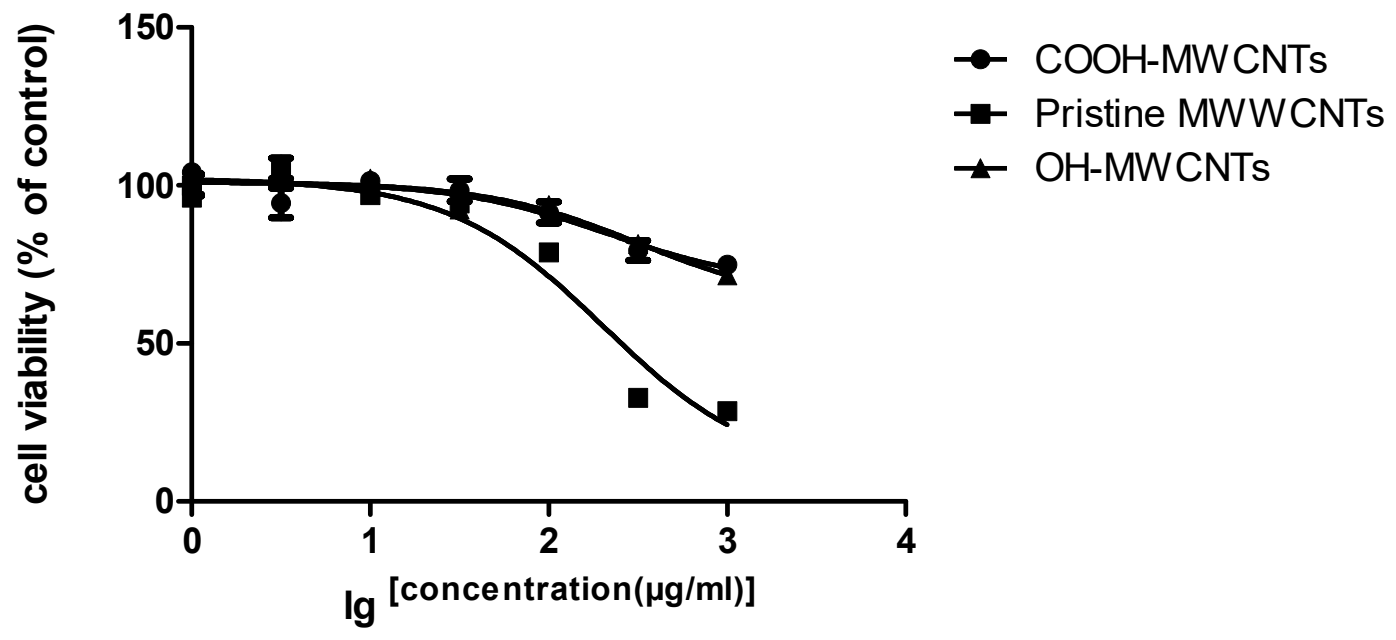


Figure 3

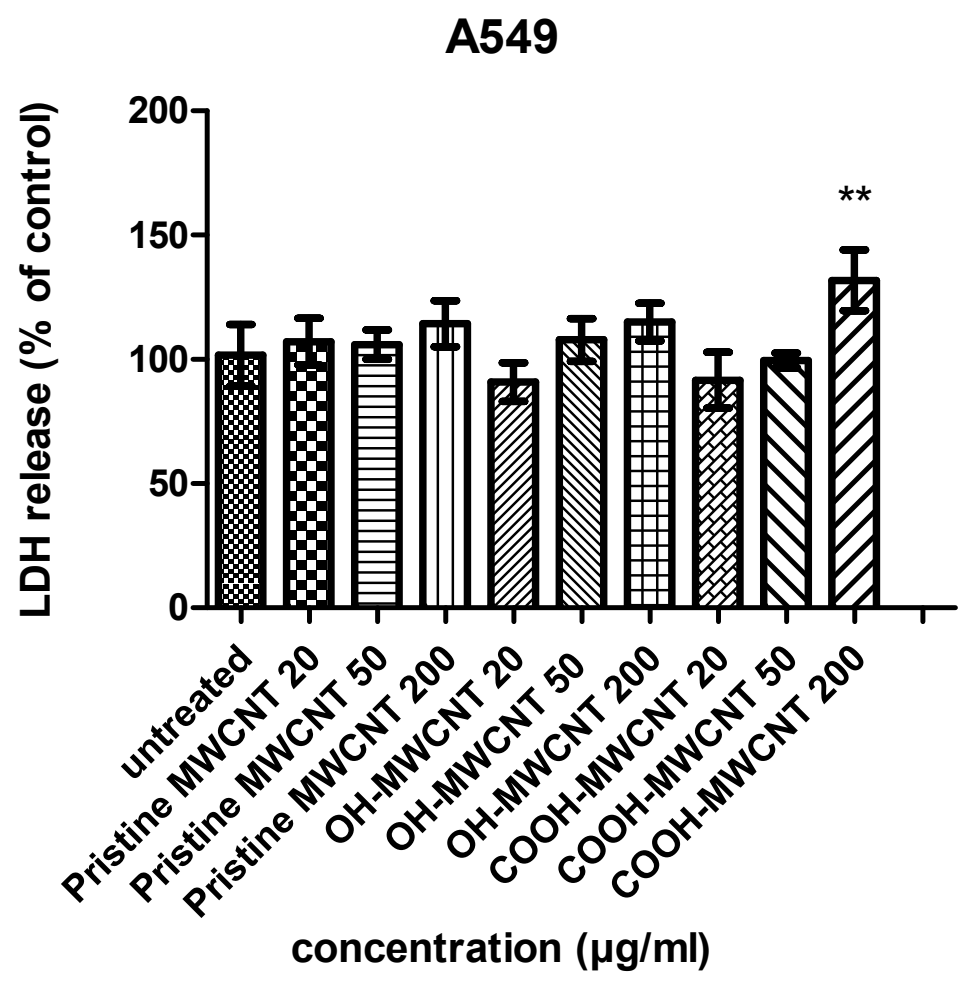


Figure 4

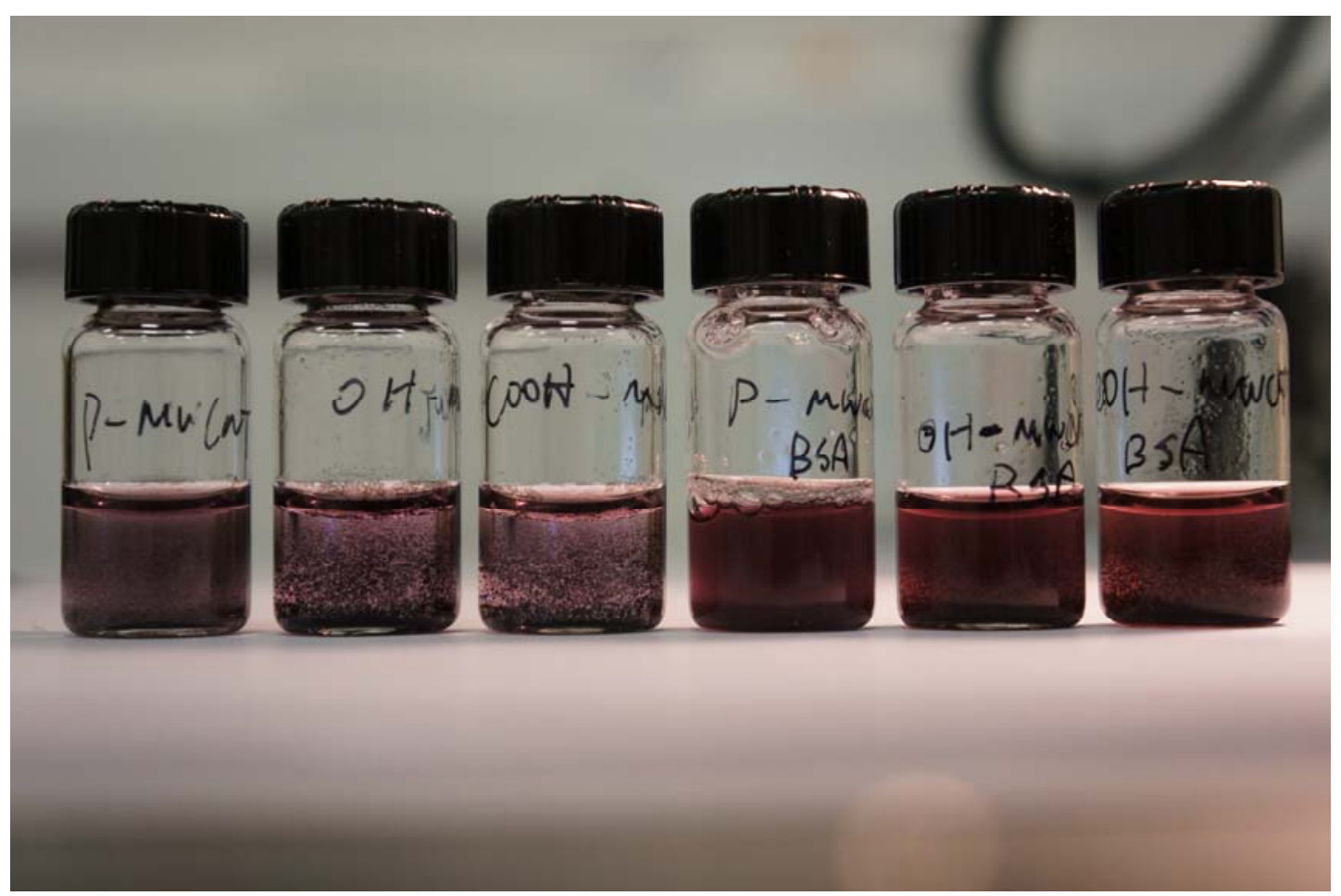


Figure 5

a

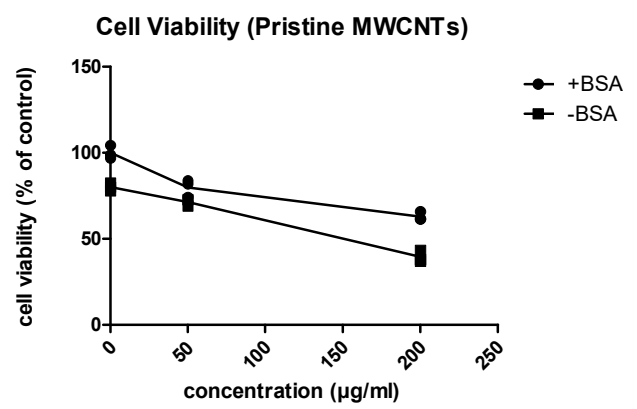

C

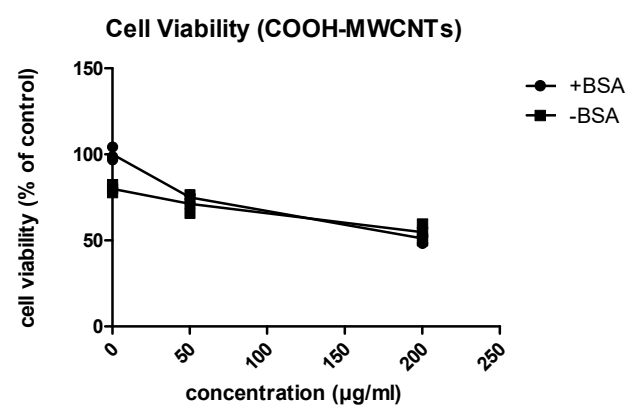

b

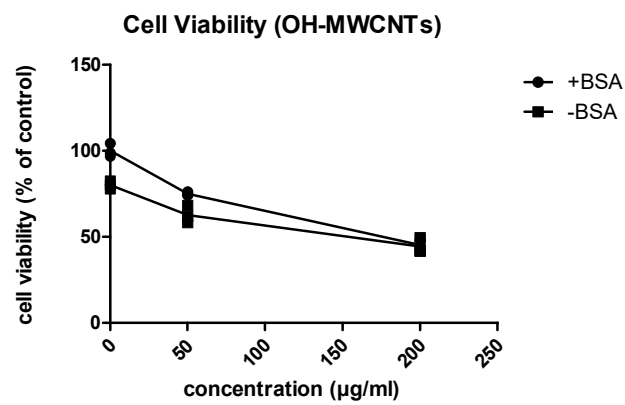


Figure 6

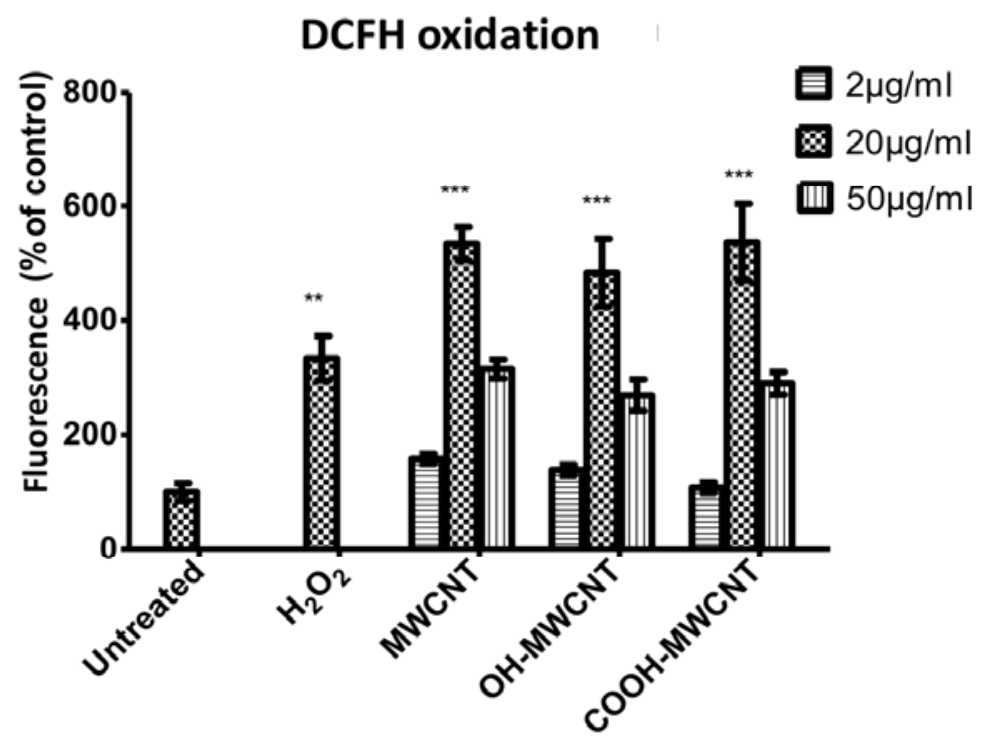


Figure 7

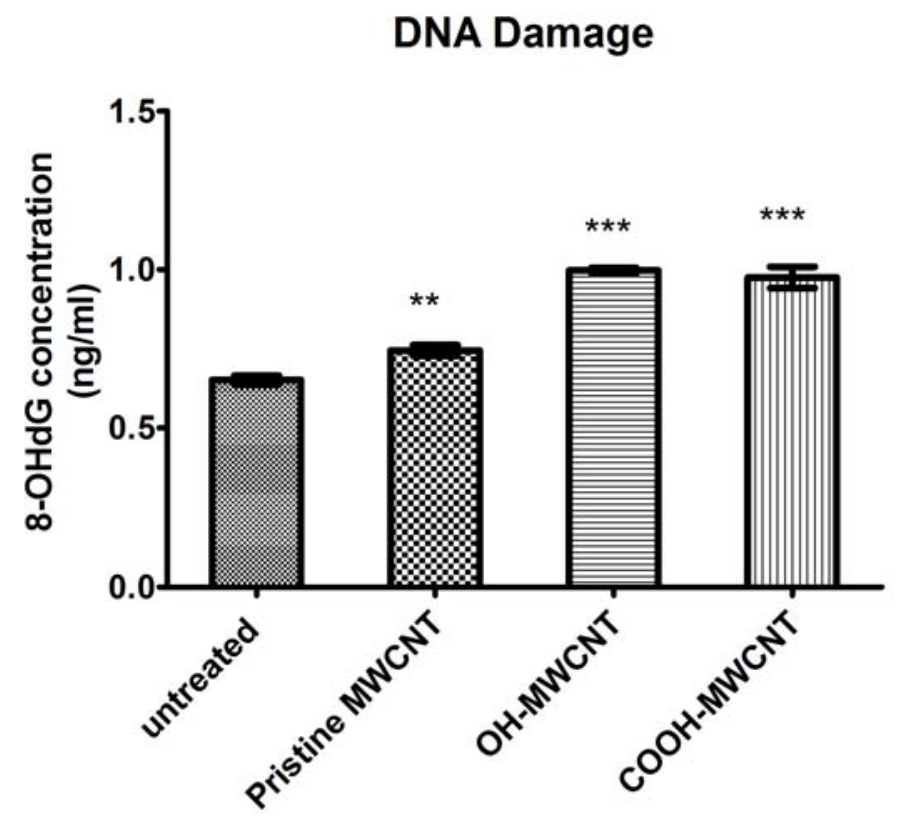


Table 1 Apoptosis induced by MWCNTs in A549 cells after $48 \mathrm{~h}$ exposure

Dose

\begin{tabular}{cccc}
$(\mu \mathrm{g} / \mathrm{ml})$ & P-MWCNT & OH-MWCNT & COOH-MWCNT \\
& \multicolumn{2}{l}{ Mean $(\%$ apoptotic cells $\pm \mathrm{SD})$} & \\
20 & $8.5 \pm 2.09^{\mathrm{a}}$ & $21.90 \pm 3.80$ & $13.50 \pm 1.58$ \\
50 & $18.8 \pm 4.31$ & $42.7 \pm 4.84^{\mathrm{b}}$ & $36.8 \pm 3.79$ \\
200 & $25.0 \pm 1.45$ & $29.7 \pm 3.40$ & $33.9 \pm 2.13$
\end{tabular}

a,b Denote significant difference $(p<0.05)$ Untreated cells showed $5.63 \pm 0.66 \%$ apoptosis 